\title{
The study of the Economic Feasibility of Using Distributed Database Technology when Building an Electronic System for Voting
}

\author{
OLENA MIKHAILUTSA \\ Department of Automation Systems Software \\ Zaporizhzhia National University \\ Zaporizhzhia, Zhukovsky Street, 66 \\ UKRAINE
}

TETIANA MELIKHOVA

Department of Accounting, Analysis, Taxation and Audit

Zaporizhzhia National University

Zaporizhzhia, Soborniy avenue, 226

UKRAINE

\author{
ANDRIY POZHUYEV \\ Department of General Education Discipline \\ Zaporizhzhia National University \\ Zaporizhzhia, Zhukovsky Street, 66 \\ UKRAINE
}

OKSANA YAROSHEVSKA

Department of Economics

Classic Private University

Zaporizhzhia, Zhukovsky Street, 70B

UKRAINE

\author{
VOLODYMYR STOIEV \\ Department of Business Economics \\ Zaporizhzhia National University \\ Zaporizhzhia, Soborniy avenue, 226 \\ UKRAINE
}

\begin{abstract}
The present article analyzes the benefits of using advanced technology of distributed databases to reduce the financial costs of various voting. At the current stage of society development and global computerization, the main attention is paid both to observing all the basic democratic components of the elections and accessibility for voters and, if possible, to a low strain on the state budget. When studying the history of the electoral institution development and analyzing contemporary issues, the attention was focused on the use of information technologies in the development of electronic voting systems. As a part of the analysis of elections economic component, the number of voters in Ukraine was investigated, the structure of the total costs of 20172019 elections, the projected figures for 2020-2021 and expenditures of the state budget of Ukraine for the Central Election Commission for 2014-2020 were analyzed. When creating the software product, the blockchain technology overview was carried out in terms of its applicability in the field of electronic voting. The developed system demonstrates the need for a distributed database technology use in modern electronic voting systems. A smart contract code has been created and developed to minimize the voting costs and to ensure the system reliability. The benefits and specificity of the proposed system are considered in the present work.
\end{abstract}

Key-Words: - Blockchain, Economic development, Electronic voting, Cost analysis

Received: October 23, 2019. Revised: April 30, 2020. Accepted: May 12, 2020. Published: May 18, 2020.

\section{Introduction}

As we know, elections are the oldest tool for forming state bodies and local self-government bodies, implemented on the principles of democracy, equality and free will. Today, in most developed countries, official voting results are established on the basis of paper protocols of election commissions with signatures and "wet" stamps. The use of this technology entails significant economic costs both for material resources and for the remuneration of labor of all individuals involved in this process. An alternative to the traditional voting system is electronic voting (e-voting) - a set of methods and tech- nologies that simplify the collection, transmission and counting of votes. In addition to the obvious economic benefits, this approach allows to increase the level of voter participation in the elections, speeds up the processing the results, makes the elections cleaner, transparent and effective under certain conditions. Nowadays, there are several electronic voting systems in the world. Systems with mechanical numbering (punch cards), which were used in the middle of the last century in the USA, appeared first. With the development of technology, this system has transformed into optical numbering, in which the device recognizes the mark on the ballot 
and counts the votes. More advanced systems are direct electronic registration systems, in which voters mark their choice on the touch screen. The received data are consolidated on a central computer then. One of the varieties of this system is the telephone network, in which the voter can identify and make his choice using the telephone keyboard. And finally, the most progressive and promising system is one that uses private computer networks or the Internet. However, the electronic voting system via the Internet has proved to encounter a number of serious difficulties. Voting systems should ensure the voter's privacy, as well as a reliable and secure means of transmitting his vote. The critical difficulty in fulfilling these requirements is caused by the unreliability of the software, the possibility of thirdparty interference through hacker attacks, and the closed voting results in case of doubt about elections credibility (since the voter does not have the opportunity to verify the correctness of his vote). In this context, a number of European countries (France, Germany) after testing this system refuse to use it.

The One way to address this issue and ensure the requirements that are put forward to electronic voting systems is to use the distributed registry technology Blockchain.

\section{Review of literature}

The development of electronic voting systems at the end of the last century aroused scientific interest and a large number of works related to the impact of the Internet on electoral law. In the article [1], the author considers both the advantages of the Internet in the political, social and economic aspects, and the issues associated with them: privacy, protection of intellectual property, taxation and "open access" to high-speed or "broadband" networks. The framework for solving these problems through the joint efforts of business and government is outlined here. Internet voting is often considered as a means of creating new opportunities for elections. As his followers emphasize, these features will help make voting more convenient and less costly. They can encourage the participation, promote direct democracy and increase voter awareness [2].

Today, the electronic voting has been fully implemented in one European state - Estonia. Work [3] is based on the experience of the Republic of Estonia in implementing and applying the electronic voting. For the first time it systemized the main advantages of introducing this system, including the involvement of the electorate in the realization of their active suffrage; the shortcomings are identified and the main conditions and adaptation factors of this system are assessed. The article [4] discusses the introduction of the latest information technologies in the electoral field related to the transmitting the voting on the Internet. The conduct of Internet elections is considered to be one of the promising areas for the development of such Concept systems with the participation of the state. The main features of the Concept project of introducing an electronic voting system in Ukraine, the problems and prospects of its implementation are analyzed here. The process of voting by a specific voter proposed by the Concept is described in detail. In addition, the foreign experience of countries actively introducing the electronic form of remote voting into the political system is highlighted. The article [5] considers the advantages and disadvantages of introducing and using the electronic voting system in different countries of the world and the prospects of introducing electronic voting in Ukraine. It is noted that edemocracy is becoming a direct tool for democratization and development of society in the information direction. The author also considers measures being developed by Ukraine to introduce an electronic voting system. Based on the experience of other countries, it was determined that electronic voting should be used in parallel with the conventional expression of will.

Evidently, the rapid development of computer science and technology has not spared the problem of the security of Internet voting. Involvement of cryptography was aimed at increasing control over voting and eliminating abuse and human errors. However, both the first automated ballot processing systems and computerized DRE-systems are vulnerable to errors and malicious actions [6].

The book [7] demonstrates more than one hundred facts of fraud and distortion of voting results due to interference in the development of equipment or software. It deals with the security problems during electronic voting. The absence of a paper confirmation of the will makes it impossible to refute the results in court.

The search for a solution to this problem is carried out using the election verification procedure. In [8], three types of verification were distinguished individual, universal, and eligibility verification. Also, aspects of hardware and software that should be trusted in order to verify the elections are highlighted. From the mathematical and software point of view, the work $[9,10]$ is devoted to solving this problem. In these works, methods of statistical testing of the blockchain using mathematical methods are considered. The work [11] is devoted to ensuring the security of information networks, the detection and prevention of intrusions, which is one of 
the main conditions for constructing electronic voting models.

A promising way to develop electronic voting is to use blockchain-enabled voting (BEV), which can reduce fraud and increase voter access. At the same time, eligible voters vote anonymously using a computer or smartphone. The article [12] discusses some implementations of BEV, as well as potential advantages and problems of this approach.

The article [13] examines in detail the world practice of using this technology in popular voting. The technical solutions used in the most actively developing projects aimed at developing their own software for electronic voting using blockchain technology are analyzed separately. The article also considers certain problems of voting using blockchain technology, such as identification and secrecy of the ballot.

Economic studies are interdisciplinary in nature, which allows the use of a scientific approach in the field of electronic voting, similar to that used by the authors in other studies. His idea is to collect data from reporting data, conduct economic analysis on the basis of statistical data and determine the cost-effectiveness of introducing electronic voting [14].

\section{$3 \quad$ Materials and methods}

\subsection{Analysis of election expenditures}

The analysis of literature has shown that holding free elections for sustainable economic development is a very relevant topic today. In 2019, parliamentary and presidential elections were held in Ukraine. Overall turnout was $62.8 \%$. The elections were prepared in advance, so ballots were printed for all voters. Many voters could not take advantage of the right to cast their vote for their candidate, and the state incurred unnecessary expenditures, which negatively affected the economic and political development of the state. According to the Law of Ukraine "On the State Register of Voters" [15], the financing of activities related to the creation, maintenance and operation of the Register is carried out at the expense of the state budget of Ukraine, and (in the case of financing the activities of local self-government bodies provided by this Law) at the expense of the respective local budgets as a financing of delegated authority. According to the Law of Ukraine "On Central Election Commission", the financing of the Commission, the Secretariat of the Commission, the patronage service, the Office of the State Register of Voters, the regional and territorial missions of the Commission is carried out at the expense of the budget [16]. On December 19, 2019 the Electoral Code of Ukraine was adopted [17]. According to the Production Code of Ukraine, expenditures for the preparation and holding of elections of the President of Ukraine, deputies, local elections, village, settlement and city heads are paid exclusively at the expense of the state budget allocated for the preparation and holding of these elections. Information on the number of voters within the Autonomous Republic of Crimea, oblasts, cities of Kyiv and Sevastopol, foreign electoral districts is available on the website of the Central Election Commission [18]. As of December 31, 2019, the number of voters in Ukraine is 35477188 people. The highest number of voters in the Dnipropetrovsk region is 2560648 people or $7.22 \%$, in $\mathrm{Kiev}$ 2191410 people or $6.18 \%$, in the Kharkiv region 2106758 people or $5.94 \%$, in the Lviv region 1946693 people or $5.49 \%$, in the Odessa region 1799326 persons or $5.07 \%$, in the Kiev region 1504064 persons or $4.24 \%$, in the Zaporizhzhia region 1390396 persons or $3.92 \%$. Based on the large number of voters, on the basis of data from the budget request for 2019-2021 (Form 2019-2) [19], we will analyze the cost of holding elections.

The analysis and structure of the general expenditures for the elections in 2017-2021 are given in Table 1. Expenditure on leadership and management in the field of elections and referendums in 2017 amounted to 295,46 thousand USD, in 2018 amounted to 4175,21 thousand USD, in 2019 according to the project amounted to 6996,10 thousand USD, in 2020 it is projected in the amount of 5384,49 thousand USD, in 2021 it is projected in the amount of 6952,36 thousand USD. The expenditures for holding the elections of the People's Deputies of Ukraine in 2018 amounted to 1182,44 thousand USD, in 2019 according to the project amounted to 73536,60 thousand USD, in 2020 and 2021 the amount is estimated at 1247,46 thousand USD. The expenditures for holding the presidential election in 2019 in accordance with the draft amounted to 88822,37 thousand USD.

Expenditures for the functioning of the State Register of Voters in 2017 amounted to 1062,59 thousand USD, in 2018 amounted to 1155,19 thousand USD, in 2019 according to the project amounted to 4757,41 thousand USD, in 2020 and 2021 the amount is estimated at 1022,33 thousand 


\begin{tabular}{|l|c|c|c|c|c|c|}
\hline Types of costs & $\begin{array}{c}2017 \\
\text { (report) }\end{array}$ & $\begin{array}{c}\text { Specific } \\
\text { weight, \% }\end{array}$ & $\begin{array}{c}2018 \\
\text { (approved) }\end{array}$ & $\begin{array}{c}\text { Specific } \\
\text { weight, \% }\end{array}$ & $\begin{array}{c}2019 \\
\text { (project) }\end{array}$ & $\begin{array}{c}\text { Specific } \\
\text { weight, \% }\end{array}$ \\
\hline $\begin{array}{l}\text { Leadership and management in the } \\
\text { field of elections and referendums }\end{array}$ & 295,46 & 73,53 & 4175,21 & 64,11 & 6996,10 & 4,02 \\
\hline Election of People's Deputies of Ukraine & & & 1182,44 & 18,16 & 73536,60 & 42,24 \\
\hline Election of the President of Ukraine & & & & & 88822,37 & 51,01 \\
\hline $\begin{array}{l}\text { Functioning of the State Register of } \\
\text { Voters }\end{array}$ & 1062,59 & 26,47 & 1155,19 & 17,74 & 4757,41 & 2,73 \\
\hline Total & 4014,27 & 100 & 6512,84 & 100,00 & 174112,49 & 100 \\
\hline
\end{tabular}

\begin{tabular}{|l|l|l|l|l|}
\hline Types of costs & $\begin{array}{l}2020 \\
\text { (forecast) }\end{array}$ & $\begin{array}{l}\text { Specific } \\
\text { weight, \% }\end{array}$ & $\begin{array}{l}2021 \\
\text { (forecast) }\end{array}$ & $\begin{array}{l}\text { Specific } \\
\text { weight, \% }\end{array}$ \\
\hline $\begin{array}{l}\text { Leadership and management in the field of } \\
\text { elections and referendums }\end{array}$ & 5384,49 & 70,35 & 6952,36 & 75,39 \\
\hline Election of People's Deputies of Ukraine & 1247,46 & 16,29 & 1247,46 & 13,52 \\
\hline Functioning of the State Register of Voters & 1022,33 & 13,36 & 1022,33 & 11,09 \\
\hline Total & 7654,28 & 100 & 9222,15 & 100,0 \\
\hline
\end{tabular}

Table 1. Analysis and structure of the total cost of elections in 2017-2021

USD. The total expenditures for the elections in 2017 amounted to 4014,27 thousand USD, in 2018 amounted to 6512,84 thousand USD, in 2019 according to the project amounted to 174112,49 thousand USD, in 2020 The forecast for the year is 7654,28 thousand USD, in 2021 it is estimated in the amount of 9222,15 thousand USD.

The structure of the general expenditures for the elections is as follows: in 2017, the expenditures for management and management in the field of elections and referendums amounted to $73,53 \%$, the costs of functioning of the State Register of Voters amounted to $26,47 \%$; in 2018 , the expenditures for the leadership and management in the sphere of elections and referendums amounted to $64,11 \%$, the expenditures for holding the elections of the People's Deputies of Ukraine amounted to $18,16 \%$, the expenditures for the functioning of the State Voter Register amounted to $17,74 \%$; in 2019 , the expenditures for holding the election of the President of Ukraine amounted to $51,01 \%$, the cost of holding the elections of the People's Deputies of Ukraine amounted to $42,24 \%$, the expenditures for the leadership and management in the sphere of elections and referenda amounted to $4,02 \%$, the cost of functioning of the State Register voters accounted for $2,73 \%$; in 2020,the estimated expenditures for the leadership and management in the sphere of elections and referendums will be 70,35\%, the expenditures for holding the elections of the People's Deputies of Ukraine will be $16,30 \%$, the costs for the functioning of the State Voter Register will be $13,36 \%$; in 2021, the estimated expenditures for the leadership and management in the sphere of elections and referendums will be $75,39 \%$, the expendi- tures for holding the elections of the People's Deputies of Ukraine will be 13,53\%, and the expenditures for the functioning of the State Voter Register will be $11,09 \%$. Elements of spending on leadership and management in the field of elections and referendums in 2017-2019 (Table 2) are examined in more detail. The structure of expenditures for leadership and management in the field of elections and referendums is as follows: in 2017, the cost of wages was $65,37 \%$, the cost of accrual of wages was $13,82 \%$, the cost of services (except utilities) was $8,12 \%$, expenditures for items, materials, equipment and inventory amounted to $6,35 \%$; in 2018 , the cost of wages was $59,11 \%$, the cost of services (except utilities) was $16,02 \%$, the cost of accrual of wages was $13,00 \%$, the cost of items, materials, equipment and inventory was $6,45 \%$; in 2019 , the planned cost of labor is planned to be $44,00 \%$, the cost of services (except utilities) is planned to be $26,65 \%$, the cost of purchasing equipment and durable goods is planned to be $13,09 \%$, the cost of accrual for payment works are planned to make $9,68 \%$, expenditures for items, materials, equipment and inventory are planned to make $4,08 \%$; in 2020 , the wage costs are planned to be $66,44 \%$, the wage bill is planned to be $14,62 \%$, the cost of services (except utilities) is planned to be $11,28 \%$, the cost of items, materials, equipment and inventory are planned to be $4,76 \%$; in 2021, the wage costs are planned to be $69,82 \%$, the wage bill is planned to be $15,36 \%$, the cost of services (except utilities) is planned to be $8,74 \%$, the cost of items, materials, equipment and inventory are planned to be $3,69 \%$. Elements of expenditures for the organization and maintenance of the State Register of Voters in 2017-2019 (Table 3), 


\begin{tabular}{|l|c|c|c|c|c|}
\hline Cost elements & $\begin{array}{c}2017 \\
\text { (report) }\end{array}$ & $\begin{array}{c}2018 \\
\text { (approved) }\end{array}$ & $\begin{array}{c}2019 \\
\text { (project) }\end{array}$ & $\begin{array}{c}2020 \\
\text { (forecast) }\end{array}$ & $\begin{array}{c}2021 \\
\text { (forecast) }\end{array}$ \\
\hline Salary & 65,37 & 59,11 & 44,00 & 66,44 & 69,82 \\
\hline Payroll & 13,82 & 13,00 & 9,68 & 14,62 & 15,36 \\
\hline Items, materials, equipment and inventory & 6,35 & 6,45 & 4,08 & 4,76 & 3,69 \\
\hline Medicines and dressings & 0,01 & 0,01 & 0,01 & 0,02 & 0,01 \\
\hline Payment for services (except utilities) & 8,12 & 16,02 & 26,65 & 11,28 & 8,74 \\
\hline Travel expenditures & 0,45 & 0,40 & 0,25 & 0,29 & 0,22 \\
\hline Payment for utilities and energy & 2,63 & 2,70 & 1,80 & 2,28 & 1,93 \\
\hline $\begin{array}{l}\text { Certain activities for the implementation of } \\
\text { state (regional) programs that are not related } \\
\text { to development activities }\end{array}$ & 0,02 & 0,04 & 0,02 & 0,02 & 0,01 \\
\hline $\begin{array}{l}\text { Current transfers to foreign governments } \\
\text { and international organizations }\end{array}$ & 0,07 & 0,31 & 0,22 & 0,26 & 0,20 \\
\hline Other current expenditures & & 0,04 & 0,20 & 0,03 & 0,02 \\
\hline Acquisition of equipment and durables & 0,81 & 0,86 & 13,09 & & \\
\hline Reconstruction and restoration & 2,35 & 1,06 & & & \\
\hline Total & 100,00 & 100,00 & 100,00 & 100,00 & 100,00 \\
\hline
\end{tabular}

Table 2. Analysis and structure of expenditure on leadership and management in elections and referenda in 2017-2021 (specific weight, \%)

\begin{tabular}{|l|c|c|c|c|c|}
\hline Cost elements & $\begin{array}{c}2017 \\
\text { (report) }\end{array}$ & $\begin{array}{c}2018 \\
\text { (approved) }\end{array}$ & $\begin{array}{c}2019 \\
\text { (project) }\end{array}$ & $\begin{array}{c}2020 \\
\text { (forecast) }\end{array}$ & $\begin{array}{c}2021 \\
\text { (forecast) }\end{array}$ \\
\hline Items, materials, equipment and inventory & 7,12 & 0,18 & & & \\
\hline Payment for services (except utilities) & 92,88 & 73,20 & 23,91 & 100,00 & 100,00 \\
\hline Acquisition of equipment and durables & & 26,62 & 76,09 & & \\
\hline Total & 100,00 & 100,00 & 100,00 & 100,00 & 100,00 \\
\hline
\end{tabular}

Table 3. Analysis and structure of expenditure on organization, maintenance and operation of the State Voter Register in 2017-2021 (specific weight, \%)

have been investigated in more detail. The structure of expenditures for the organization and maintenance of the State Voter Register in 2017 is as follows: expenditures for services (except utilities) amounted to $92,88 \%$, expenditures for items, materials, equipment and inventory amounted to $7,12 \%$; in 2018, the cost of services (except utilities) was $73,20 \%$, the cost of purchasing equipment and durable goods was $26,62 \%$, the cost of items, materials, equipment and inventory was $0,18 \%$; in 2019 , the planned costs for the purchase of equipment and durable goods will be $76,09 \%$, the cost of services (except utilities) will be 23,91\%; in 2020 and 2021, the planned cost of services (except utilities) will be $100 \%$.

The expenditures of the state budget of Ukraine on the Central Election Commission amounted : in $2014-116.79$ million USD, which is $0.32 \%$ in the structure of budget spending communities, in 2015 5.31 million USD $(0.02 \%)$, in 2016 - 4.96 million USD $(0.02 \%)$, in 2017 - 4.01 million USD $(0.01 \%)$, in 2018 - 6.64 million USD (0.02\%), in 2019 161.90 million USD $(0.40 \%)$, in the 1 st quarter of 2020 -17.95 million USD (0.22\%) (Fig. 1) [20].

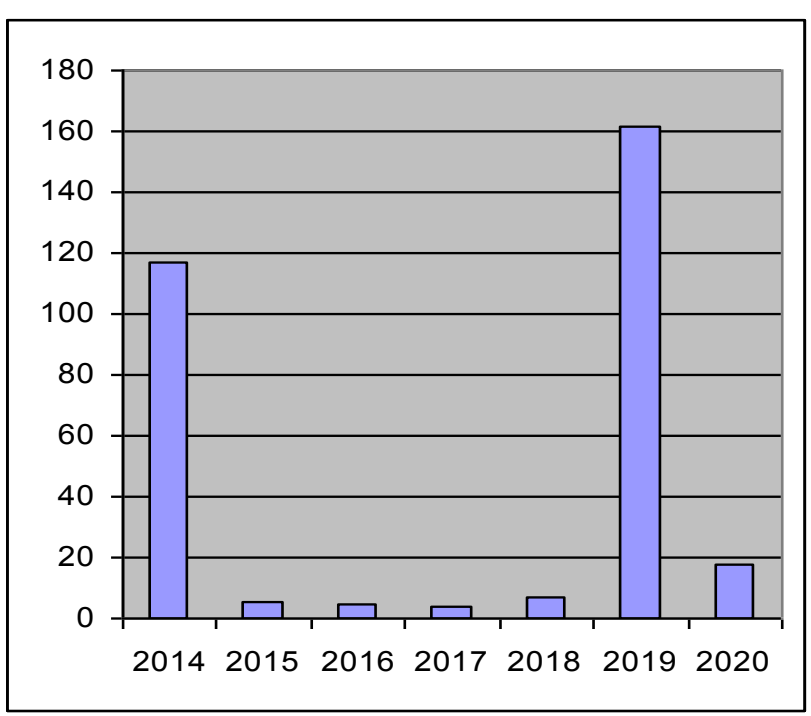


Fig. 1 Dynamics of expenditures of the state budget of Ukraine on the Central Election Commission High costs of the Central Election Commission in 2014 and 2019 are explained by the presidential election. In 2020, the increase in costs is associated with the transition to new technologies, the introduction of which require initial costs for the purchase of equipment and the development of computer programs.

So, now Ukraine spends much costs for elections annually. Unfortunately, outdated election technology is currently being applied in Ukraine, which has a negative impact on the country's sustainable economic development. Currently, everyone uses a smartphone, a computer; most people have access to the Internet, so it is possible to switch to "eelections" or "e-voting". "Electronic voting" is a fixation of the will of voters using electronic technologies, which covers both the voting process and the process of automatic counting of votes by electronic devices and special software [21]. In order to ensure sustainable economic development of the country, the President emphasized the introduction of opportunities for Ukrainians to vote using smartphones and the Internet [22].

The electronic voting system can be used for any vote, for example, elections of a rector, dean, head of department, professor, associate professor, senior lecturer or assistant in higher education institution; in the regional or local state administration to select the best project; when conducting different competitions and others. Paper-based voting spends a lot of time organizing and holding elections, as well as counting votes; also, costs are spent on remuneration, Single Social contribution, different materials, equipment depreciation, business trips and other expenditures. Electronic voting can be held anywhere, and a voter won't miss the opportunity to cast his vote. The e-voting system also has special system protection to avoid fake elections. In the age of electronic technology, the timely information and saving of time and cost are highly appreciated. The introduction of electronic voting in Ukraine, both at the state level and at the level of state institutions, leads to economic growth.

\subsection{Blockchain Technology Overview}

In general, it is believed that blockchain applications are a very promising technology, however, they are still in the early stages of development. At first, the only area of application for blockchain devices and systems was financial structure. At present moment, technology has expanded the scope of opportunities, and has found application in many other related areas of monetary distribution. There are many exam- ples of the application of this technology not only in banking, financial, technical and market structures. Recently, a number of companies have been created and individual projects have been launched, the purpose of which is to apply the principles of blockchain in various industries, including copyright, energy, the field of computer cyber games, intellectual Internet of things, including the field of electronic voting.

The idea of using blockchain in voting systems seems obvious: blockchain allows to replace the ancient voting technology by transferring someone's voice expressed by a physical object to a digital token [23]. At the same time, as in many other cases of the transition of a business process from the physical world to the digital one, transaction costs are sharply reduced and the availability of the system is increased. Moreover, the use of the blockchain provides extra benefits, among which there are: genuine results, transparency of the process, anonymity and speed of data processing. The development of a public voting platform will allow users to cast their votes anywhere, which will increase voters overturn among citizens. Blockchain is a technology with an open transaction registry, and therefore everyone can check whether the information about his vote was correctly saved. In addition, each transaction is checked immediately by a large number of computers, and therefore it is almost impossible to fake the results. Regarding the centralization, the basic idea of the blockchain immutability is achieved when thousands of copies are held by independent participants. A decentralized blockchain is more protected from falsification of entries in it.

The main and priority feature of the blockchain is the use of mathematical calculation algorithms, as well as the exclusion of the "person" and the human factor when making decisions by the system [24]. One of the main problems of the blockchain is the reliability of the data. This determines the need for effective encryption algorithms. They should guarantee sufficient cryptographic inviolability for information on the network, as well as enable the implementation of a digital signature. So, blockchain technology is a kind of symbiosis of cryptography and computerization. The blockchain technology is based on a transactional model: each user has a wallet with unique public and private keys, by which he confirms any data change. All transaction information is stored in sequentially written blocks, so the data hash of the previous block is included in the data of the next. This ensures the immutability of the data - any block change will automatically invalidate all subsequent ones. The blockchain stores all 
the information about all transactions in full simultaneously on all nodes, and it cannot be changed or deleted.

\subsection{Software system capabilities}

Basing on the analysis of electronic voting devices and electronic voting itself, as well as the technology presented, a full-fledged prototype of an electronic system was created for voting with the advanced technology use of distributed databases. The developed system contains six main architectural blocks:

- Front-end. It is implemented on the basis of the JavaScript Vue.js framework, the library of which allows you to significantly reduce, simplify and improve the development process of modern interactive applications.

- Back-end. A server for providing an API for interacting with a database. Back-end is built on the basis of Node.js Express framework, to ensure the processing of a large number of parallel requests. It uses an asynchronous code launch model based on processing events in non-blocking mode and defining callback handlers.

- AWS Cognito. Amazon Cognito is an authorization service which allows you to quickly and easily add the ways to register, authorize and control user access to mobile and Internet applications, and also provides a secure user directory that can be scaled to hundreds of millions of users.

- Database server. MongoDB, an open source document-oriented database management system, is responsible for storing information in the system.

- Smart contract. When deployed on a network, the blockchain contract is responsible for maintaining and processing the voting status on the network. The developed smart contract code minimizes the cost of voting and ensures the reliability of the system.

- Blockchain network. It is a distributed database that stores voting data. In fact, a duplicate of this data is stored on the system database server.

There are five basic entities in the system:

- Profile. It represents a user, includes his data and an encrypted wallet.

- Voting. It includes data about voting itself.

- Member. It represents a request to vote.

- Variant. It represents a voting option.

- Voice, it is a choice of the participant in the voting.

The developed system has full-fledged modules that interact with each other. An authorized user has the opportunity to vote and create their own modules. At the first login, the user enters a password to encrypt his wallet (which is generated to enable the user to send requests for participation). For each individual vote, a smart contract is generated and deployed in the system. All confirmed participants are entitled to cast their vote after the voting starts. The results are stored in the database and on the blockchain, everyone can review their transaction and identify errors or fraud during the voting (if any). The implemented system is recommended for use by companies, civic organizations, universities and the like.

\section{Conclusion}

The paper analyzed the economic component of the elections, reviewed the structure of the total costs of the elections for 2017-2019, predicted indicators for 2020-2021, as well as the expenditures of the state budget of Ukraine for the Central Election Commission for 2014-2020. Cost analysis for the election organization and its conduction showed that the current form of election is quite expensive for the budget of Ukraine.

The study of the structure of the general expenditures for the election conduction for 2017-2019 and the predicted indicators for 2020-2021 showed that each year the proportion of expenditures for elections changes depending on the legislatively established frequency of the relevant elections. In 20172018, the largest expenses were for leadership and management in the field of elections and referenda, as well as for the elections of people's deputies of Ukraine, significantly lower expenses were for the functioning of the State Register of Voters. In 2019, the most funds were spent on the organization of the election of the President of Ukraine and people's deputies of Ukraine. In 2020-2021, it is predicted that the largest amounts will be spent on governance in the field of elections and referenda.

A study of the structure of management costs in the field of elections and referenda in 2017-2021 showed that the largest are the costs for: remuneration, payroll, payment of services (except utilities), items, materials, equipment and inventory. A study of the cost structure for organizing the maintenance of the State Register of Voters showed that in 2019 expenditures for the equipment purchase and durable goods increased by 3 times compared to 2018 . According to the predicted data, in 2020 and 2021, only payment expenditures of services are plannedThis study formed the basis for confirming the need to create an application using distributed database technologies.

For the sustainable development of the state, it is necessary to optimize costs, introduce new technologies and reduce the extra funds wasting by intro- 
ducing an electronic voting system. The introduction of electronic voting in Ukraine both at the state level and at the level of state structures will lead to the economic growth of state institutions and the country as a whole.

The analytical research method was used to identify the possibilities of using blockchain technology to build an electronic voting system. Methods of observation and comparison were used to reveal the weaknesses of existing analogues. A full-fledged prototype of an electronic system for voting using blockchain technology was created. The expediency and even necessity of using the technology of distributed databases in such systems was discovered. A smart contract code was invented and developed that minimizes the cost of voting and ensures the reliability of the system.

The use of blockchain technology in voting helps to solve most of the problems of existing electoral systems. The use of services such as a developed prototype can be overall in the near future, ranging from voting in a separate company to voting at the state level. It is also possible to improve the existing system by implementing additional options for individual voting and introducing user-friendly functions not related to databases.

\section{References:}

[1] R.E. Litan, Law and Policy in the Age of the Internet, Duke Law Journal, Vol.50, 4, 2001, pp. 1045-1085.

[2] N. Kersting, Electronic Voting and Democracy in Europe, Politicheskaya nauka, № 4, 2007, pp. 123-144.

[3] A.V. Ruchki and A.A. Chizhov, Electronic voting in elections to state authorities and local self-government: Estonian experience, Voprosy upravleniya, № 5(35), 2018, pp. 54-60.

[4] M.YU. Mostovaya, E-democracy in the electoral system of Ukraine: the long-awaited reality or Utopia? Visnik Mariupol's'kogo derzhavnogo universitetu, Ser.: Pravo, Vol.5, 2013, pp. 218-222.

[5] YU.A. Dan'ko, and N.H. Bilotserkivs'ka, Electronic voting: opportunities of the Ukrainian reception, Suchasne suspil'stvo, Vol. 1(17), 2019, pp. 60-72.

[6] T. Lauer, The risk of e-voting, Electronic Journal of e-Government, 2004, pp. 177-186.

[7] B. Harris, Black box voting: ballot tampering in the $21^{\text {st }}$ Century, Renton, WA, 2004.

[8] S. Kremer, M. Ryan and B. Smyth, Election verifiability in Electronic Voting Protocols. ESORICS 2010: 15th European Symposium on
Research in Computer Security 6345, 2010, pp. 389-404.

[9] F. Kuznetsov, M. Lutsenko, K. Kuznetsova, O. Martynyuk, V. Babenko and I. Perevozova, Statistical testing of blockchain hashing algorithms. CEUR Workshop Proceedings, vol. 2588, 2019, pp. 67-79, http://ceur-ws.org/Vol$2393 /$.

[10] V. Krasnobaev, A. Kuznetsov, V. Babenko, M. Denisenko, M. Zub and V. Grigorenko, A method for increasing the numbers represented in the system of residual classes to an arbitrary degree of a natural number, 2nd IEEE Ukrainian Conference on Electrical and Computer Engineering (UKRCON), 2019, July 2-6, Lviv, Ukraine, pp. 1133-1138, doi:10.1109/ UKRCON.2019.8879793.

[11] A. Kuznetsov, S. Kavun, O. Smirnov, V. Babenko, O. Nakisko and K. Kuznetsova, Monitoring malware in computer networks of promising intelligent networks. Paper presented at the 2019 IEEE 6th International Conference on Energy Intelligent Systems, ESS 2019, Proceedings, No. 8764228, pp. 347-352. doi:10.1109/ ESS.2019.8764228

[12] N. Kshetri and J.Voas, Blockchain enabled eVoting, IEEE Software, 35(4), 2018, pp. 95-99.

[13] D.L. Kuteynikov, Features of the application of technologies of distributed registers and block chains (blockchain) in popular elections, $A k$ tual'nyye problemy Rossiyskogo prava, № 9(106), 2019, pp. 41-51.

[14] T. Melikhova, A. Makarenko, O. Mikhailytsa and A. Pozhuyev, Model of Bankruptcy Probability Based on the Analysis of Industrial Enterprises of Ukraine, CEUR Workshop Proceedings, vol. 2422, 2019, pp. 226-236, http://ceurws.org/Vol-2422/paper18.pdf.

[15] Law of Ukraine on the State Register of Voters (Information of the Verkhovna Rada of Ukraine, 2007), https://zakon.rada.gov.ua/ laws/show/698-16.

[16] Law of Ukraine on the Central Election Commission (Information of the Verkhovna Rada of Ukraine, 2004), https://zakon.rada.gov.ua/ laws/show/1932-15.

[17] Election Code of Ukraine (Official Bulletin of Ukraine, 2020), https://zakon.rada.gov.ua/laws/ show/396-20.

[18] State Register of Voters (The official website), https://www.drv.gov.ua.

[19] Budget request for 2019-2021 (Order of the Ministry of Finance of Ukraine, 2018), 
https://kyivaudit.gov.ua/pdf/bz/2019 4311070 37203257_BZ_F2 17783.pdf.

[20] The expenses of the state budget of Ukraine (Information of the Ministry of Finance, 2020), https://index.minfin.com.ua/finance/budget/ gov/expense/

[21] O. Petrovets, Operation "Electronization", or Is Ukraine Ready for Online Elections? (Ukrayins'ka pravda, 2019), https://www.pravda.com.ua/ columns/2019/03/ $\underline{18 / 7209309 .}$

[22] Ukrainians can vote in elections with help of smartfone - Zelensky (TSN - Ukraine, 2020), https://tsn.ua/ukrayina/ukrayinci-zmozhutgolosuvati-na-viborah-za-dopomo goyusmartfonu-zelenskiy-1487055. html.

[23] B. Kelly, The Bitcoin Big Bang, B. Kelly, 2014.

[24] A. Norman, Blockchain Technology Explained: The Ultimate Beginner's Guide About Blockchain Wallet, Mining, Bitcoin, Ethereum, Litecoin, Zcash, Monero, Ripple, Dash, IOTA And Smart Contracts, Kindle edition, 2017. 